WISSENSCHAFTSZENTRUM BERLIN FÜR SOZIALFORSCHUNG

SOCIAL SCIENCE RESEARCH CENTER BERLIN

\author{
Jo Seldeslachts * \\ Tomaso Duso ** \\ Enrico Pennings ***
}

\title{
On the Stability of Research Joint Ventures: Implications for Collusion
}
* Wissenschaftszentrum Berlin (WZB)
** Humboldt University and
Wissenschaftszentrum Berlin (WZB)

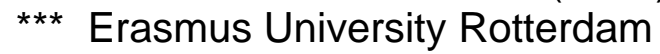

SP || $2008-15$

April 2008

ISSN Nr. $0722-6748$

Research Area

Markets and Politics

Research Unit

Competition and Innovation
Schwerpunkt II

Märkte und Politik

Abteilung

Wettbewerb und innovation 
Zitierweise/Citation:

Jo Seldeslachts, Tomaso Duso, Enrico Pennings, On the Stability of Research Joint Ventures: Implications for Collusion, Discussion Paper SP II 2008 - 15, Wissenschaftszentrum Berlin, 2008.

Wissenschaftszentrum Berlin für Sozialforschung gGmbH, Reichpietschufer 50, 10785 Berlin, Germany, Tel. (030) 25491 - 0 Internet: www.wzb.eu 


\section{ABSTRACT}

\section{On the Stability of Research Joint Ventures: Implications for Collusion *}

by Jo Seldeslachts, Tomaso Duso and Enrico Pennings

Though there is a body of theoretical literature on research joint venture (RJV) participation facilitating collusion, empirical tests are rare. Even more so, there are few empirical tests on the general theme of collusion. This note tries to fill this gap by assuming a correspondence between the stability of research joint ventures and collusion. By using data from the U.S. National Cooperation Research Act, we show that large RJVs in concentrated industries are more stable and hence more suspect to collusion.

Keywords: Research Joint Ventures, Product Market Collusion, Empirical Test

JEL Classification: L24, L44, L52

ZUSAMMENFASSUNG

Zur Stabilität von Forschungs-Joint-Ventures und ihrer Bedeutung für Kollusionen

Trotz einer Vielzahl von theoretischen Studien, die zeigen, dass Kollusion durch Forschungsallianzen erleichtert werden kann, fehlen empirische Arbeiten, die diesen Zusammenhang bestätigen. Noch erstaunlicher ist die allgemein geringe Anzahl von empirischen Untersuchungen auf dem Forschungsgebiet der Kollusion. Dieser Aufsatz versucht diese Lücke zu schließen wobei unterstellt wird, dass ein Zusammenhang zwischen der Stabilität von Joint-Ventures und der Entstehung von Kollusionen besteht. Anhand von Daten des U.S. National Cooperation Research Act zeigen wir, dass große Forschungsallianzen in stark konzentrierten Branchen stabiler und daher eher der Absprache verdächtig sind. 


\section{Introduction}

Although joint R\&D activities among firms are encouraged everywhere today, the same old suspicion still lingers: does cooperation in R\&D facilitate product market collusion? Given that so many firms participate in research joint ventures (RJVs), it is important to get a clearer view on this issue. On a more general level, empirical studies testing the theoretical predictions of collusion are relatively rare because of problems of selection bias and a lack of adequate data (Levinstein and Suslow, 2006). This paper constructs and applies an indirect test of collusion through RJVs.

We build upon the conjecture that RJVs may facilitate product market collusion. ${ }^{1}$ A necessary condition for RJVs to be used as collusive devices seems their stability. Cabral (2000, p1041), for example, states that "Firms may delay innovation [and stay in the RJV] with the sole purpose of maintaining a sufficiently credible punishment for cheating on the price agreement”. ${ }^{2}$ Indeed, RJVs make collusion in the product market easier, but only when participants are effectively able to use the RJV as a coordination or punishment device. When a firm is observed to leave the RJV, it is likely that the intended collusion was not sustainable or that the RJV was started for reasons unrelated to collusion. Similarly, the stability of collusive agreements is negatively affected by a firm’s entry (Vasconcelos, 2004). Therefore, when a firm enters an RJV after its initial formation, it is less likely that this RJV (still) serves collusion.

Suspicion of collusion is especially relevant for large-scale cooperations between firms operating in the same industry. In a general context, Stigler (1950) realized that firms outside the collusive agreement have incentives to freeride, which makes relatively smaller agreements

\footnotetext{
${ }^{1}$ RJVs may induce collusion through creating common assets - and therefore common interests - among participating firms and provide therefore a credible punishment mechanism (Cabral, 2000; Martin, 1995). This idea is reminiscent of Bernheim and Whinston's (1990) theory of multi-market contact: firms that interact in more than one market are able to sustain collusion more easily. RJVs may further induce collusion when being used as a vehicle for the transmission of information to signal cooperative behavior (Cooper and Ross, 2007).

${ }^{2}$ Martin (1995, p. 734) makes a similar argument: "The threat to break up an R\&D joint venture can form part of a fallback strategy that will sustain tacit collusion on product markets." Catilina and Feinberg (2006) model RJV participation and collusion decisions as a coalition formation game. They find that when both decisions are taken simultaneously, the stability of the RJV and product market collusion are one-to-one related.
} 
unstable. Therefore, it is hypothesized that more RJV participants increase the stability of the RJV. Noticeably, large RJVs in high concentration industries are of concern. Both higher rewards of colluding and easier detection of defection make these industries more interesting for collusion (Ordover and Baumol, 1988; Levinstein and Suslow, 2006). This leads us to test if the stability of the RJV, and hence, as supposed, the incidence of collusion, is significantly affected by industry concentration when the RJV is relatively large.

To be fair, large research collaborations may serve their purpose, i.e. induce more research and learning. These learning dynamics lead firms to exit (Reuer and Zollo, 2005) and new firms to enter in the expectation to learn in this RJV. Therefore, we set as a necessary condition for a large RJV to be research-active (as opposed to facilitating collusion) its non-stability. Non-profit entities, such as universities and governmental research bodies, do not compete with firms in the product market. It seems therefore clear that their presence has a positive impact on (expectations of) learning (Sinha and Cusumano, 1991), but a negligible impact on collusive effects. We thus propose a second test to see whether large RJVs with non-profit members are less prone to be stable, and thus more likely to be research-active.

The collaborations we investigate are set up under the US National Cooperative Research Act (NCRA). By granting certain antitrust exemptions, the NCRA stimulates firms operating in the same industry to cooperate in R\&D on a large scale. The aim of the NCRA is to provide a solution to perceived competitive threats to U.S. high-tech industries, and has been a great success (see e.g. Vonortas, 1997). But, given their large scale and that members are competitors, there may be particular suspicion of firms using the NCRA-RJVs as vehicles for product market collusion, which makes them of particular interest for our study.

We build a simple econometric framework to determine which factors explain an RJV's stability. Controlling for the heterogeneity due to size differences through size dummies, we 
investigate in a probit regression whether large RJVs' stability is affected in a different way by their product market's HHI and the presence of non-profit members. We control for other characteristics - including industry and year of formation dummies - that we expect to influence the probability of stability.

The results indicate that RJVs are more stable in highly concentrated industries, but only when the RJVs are relatively large; the suspicion of collusion may therefore be justified. We also find some support for a negative impact of non-profit entities on the stability of the larger RJV. Given our results, it is desirable to go into more detail about which of these NCRA-RJVs can be identified as vehicles for collusion. Goeree and Helland (2007) also provide some recent (indirect) empirical support for the hypothesis that RJVs facilitate collusion. Analyzing NCRA-RJVs in the telecom industries, their paper exploits the variation in RJV formation generated by a more stringent U.S. antitrust stance towards collusion. If product market collusion is not a motivation to form an RJV, they argue, the propensity to enter into an RJV should not be affected by this change. By finding a lower RJV-participation after the policy, the authors conclude, as our study does through a different test using information on all sectors, that the NCRA-RJVs are suspect of being used for collusion.

The structure of the paper is as follows. The next section discusses data and modeling issues. Section 3 discusses the main findings. Finally, in section 4, we conclude.

\section{Data and Modeling Issues}

Our main data set consists of information on the 785 formed NCRA-RJVs over the period 19851999. Among the RJVs formed under the NCRA, slightly more than two-thirds (548) did not experience the entry or exit of any firm in any year of existence after their initial formation. We therefore define the main variable of interest to be a dummy (STABLE) that takes on the value of 
one if the RJV did not experience any in-and-out movement during its lifespan, and zero otherwise. By doing this, we implicitly consider the entire RJV's life as a single observational point. This is not crucial for the issue we want to study. Indeed, time does not play an important role in the analysis, as we are interested in questioning why no changes occurred during the sample period. $^{3}$

We then matched the RJV data with the Compustat North America database containing information on about 22,000 public U.S. firms (1986-1999). Each NCRA-RJV is linked to an industry by using the assigned RJV's SIC2 code and the year as matching keys. For each industry (defined at the SIC2 level) and for each year, we calculate a measure of concentration (HHI), as well as medians and standard deviations for several other indicators, such as number of employees and R\&D intensity. Given that we collapse the RJV's life into one observation, we average the according industry characteristics over the number of periods for which the RJV is observed. While table 1 gives a short description of the main variables, in table 2 we report preliminary statistics for some relevant characteristics in the two sub-samples of stable vs. unstable RJVs. The central point of this note is to connect an RJV's behavior to its product market's concentration. Stable RJVs are found in slightly less concentrated industries; the HHI equals 0.07 in the stable sub-sample vs. 0.08 in the non-stable sub-sample (see table 2). A second factor of interest is how an RJV's stability is linked to the number of non-profit members. Stable RJVs are found to include fewer non-profit entities (NON_Profit equals 0.33 vs. 0.75). We further control for relevant industry variables, as well as for the number of links an RJV has with other RJVs (for a detailed discussion of these variables, see Duso et al., 2007).

The most eye-catching difference between stable and non-stable RVs, however, is the fact that stable RJVs are almost three times smaller than unstable ones in terms of participating for-

\footnotetext{
${ }^{3}$ Time might play a role in the sense that different RJVs are observed for a different number of time periods in the sample. We therefore control in the regressions for this issue by means of year-of-formation dummies.
} 
profit firms in the year of RJV-formation (SIZE: 6.4 vs. 16.4 respectively). ${ }^{4}$ This is of course a statistical artifact since initially larger RJVs have, all else being equal, a higher probability of experiencing the exit of one of its members; we therefore have a closer look at the frequency of stable RJVs in relation to their size in table 3. Although the frequency of stable RJVs decreases almost steadily with the number of for-profit members, a sizeable proportion of medium-sized and large RJVs is stable. Hence, to assess the drivers of stability, we need to control for the heterogeneity due to size differences. For this purpose, in our statistical analysis we partition the RJVs into three size classes: small (up to three initial for-profit members), medium (4 to 9 initial for-profit members), and large (more than 10 initial for-profit members). ${ }^{5}$

We now propose a simple econometric framework to determine which factors explain an RJV's stability. We first control for the heterogeneity due to size differences through dummies for size classes $\left(s_{j}\right)$. Second, we account for the fact that an RJV's size might affect in a different way how product market's and RJV's characteristics influence its stability. Indeed, we argue that research cooperations might be used as a coordination device to collude in the product market, and that this problem may be more relevant when the RJV is large and embedded in a more concentrated industry. Second, we contend that learning might create dynamics in RJVs, where this is more likely to happen in large RJVs with more non-profit organizations participating. Hence, we model a size-dependent impact of product market concentration (HHI) as well as the number of non-profit members (NON_PROFIT) on an RJV's stability. Finally, we control for other characteristics $(X)$ - including industry and year of formation dummies - that we expect to

\footnotetext{
${ }^{4}$ We focus on initial size to explain whether an RJV is stable along its lifetime in order to avoid endogeneity problems. Furthermore, initial size seems a more natural choice than, for example, the average number of firms participating in the RJV over its existence since it allows us to predict an RJV's behavior just by looking at its initial composition. For a full analysis of RJV dynamics, see Duso et al. (2007).

${ }^{5}$ While it is clear that RJVs with up to 3 members are qualitatively different from the others in terms of dynamics, the definition of medium-sized RJVs is subjective. We chose to define as large RJV the top $20 \%$ of the size distribution. However, we tried with other classifications --including more size classes-- and the qualitative results were not affected.
} 
influence the probability of stability. The probit regression to explain why RJV $i$ in size class $j$ is stable, is therefore the following

$$
S T A B L E_{i}=\sum_{j \mid j \neq S M A L L} \alpha_{j} s_{i j}+\sum_{\mathrm{j}} \beta_{\mathrm{j}} s_{i j} H H I_{i}+\sum_{j} \gamma_{\mathrm{j}} \mathrm{s}_{\mathrm{ij}} \mathrm{NON} \_ \text {PROFIT } \mathrm{i}+\delta \mathrm{X}_{i}+\varepsilon_{i},
$$

where $\varepsilon_{i}$ is a i.i.d. error term.

\section{Results}

Table 4 reports the results of the Probit estimation of equation (1). As expected, the probability of being stable decreases with the size groups: Medium and large RJVs have respectively $48 \%$ and 79\% lower probability of being stable than small RJVs.

Large RJVs may be used as a vehicle for collusion in the product market, and stability of these large collaborations is a necessary condition for this to be true. Consistent with this idea, we estimate a strongly positive and statistically significant effect of the industry's concentration on the probability of being stable, and this only for large RJVs; a $10 \%$ increase in the HHI induces a $27 \%$ higher probability of a large RJV being stable. Interestingly, this effect is not significant for medium and small RJVs, which provides further evidence for our claim that especially large RJVs may be potentially used as a vehicle for collusion. Second, the presence of non-profit entities significantly decreases the probability of being stable, yet again only for large RJVs; a 10\% increase in the log of the number of non-profit insiders decreases the probability of being stable by almost one percent. This suggests that large RJVs with non-profit organizations are effectively used for the main purpose of the NCRA. Firms cooperate in R\&D and learn, which leads firms to exit and new firms to enter in the expectation to also learn.

Other industry characteristics also matter for stability, yet their effects do not depend on the 
size. ${ }^{6}$ First, industry size asymmetries appear to increase stability. Second, the probability of being stable significantly decreases by $63 \%$ in the high-tech software industries, suggesting a more active learning in these potentially high-spillover industries. Finally, our model is performing well in predicting RJVs' behavior; it correctly classifies more than $83 \%$ of the observations and, most interestingly for this study, over $90 \%$ of the stable RJVs.

\section{Conclusions}

By using data from the U.S. National Cooperation Research Act, it is shown that large RJVs in concentrated industries are more stable and hence more suspect to collude. Large RJVs in which many non-profit organizations participate, on the other hand, have a lower propensity to be stable and are expected to mainly exist for research purposes. On a more methodological level, ours may be seen as an alternative test for collusive behavior through RVJ participation, which does not suffer from the typical problems of direct tests.

\section{References}

Bernheim, B.D. and M.D. Whinston, 1990, Multi-market Contact and Collusive Behaviour, Rand Journal of Economics Vol. 21, 1-26.

Cabral, L., 2000, R\&D Cooperation and Product Market Competition, International Journal of Industrial Organization, Vol. 18, 1033-1047.

Catilina E. and R. M. Feinberg, 2006, Market Power and Incentives to Form Research Consortia, Review of Industrial Organization Vol. 28, 129-144.

Cooper, R. and T. Ross, 2007, Sustaining Cooperation with Joint Ventures, Journal of Law,

\footnotetext{
${ }^{6}$ We tested whether the coefficients were size dependent. Given that it was not the case, we estimated an average effect, which allows a more efficient estimation.
} 
Economics and Organization, Forthcoming.

Duso, T., E. Pennings and J. Seldeslachts, 2007, The Dynamics of Research Joint Ventures: A Panel Data Analysis, Working Paper SP II 2007-11 Wissenschaftszentrum Berlin.

Goeree, M. and E. Helland, 2007, Do Research Joint Ventures Facilitate Collusion?, Mimeo Claremont College.

Levinstein, M.C. and V.Y. Suslow, 2006, What Determines Cartel Success, Journal of Economic Literature, Vol. 44, 43-95.

Martin, S., 1995, R\&D Joint Ventures and Tacit Product Market Collusion. European Journal of Political Economy Vol. 11, 733-741.

Ordover, J. and A. Baumol, 1988, Antitrust Policy and High-Technology Industries, Oxford Review of Economic Policy Vol. 4, pp. 13-34.

Reuer, J. and M. Zollo, 2005, Termination Outcomes of Research Alliances, Research Policy Vol. 34 (1), 101-115.

Sinha, D. and M. Cusumano, 1991, Complementary Resources and Cooperative Research: A Model of Research Joint Ventures among Competitors, Management Science, Vol. 37 (9), 10911106

Stigler, 1950, Monopoly and Oligopoly by Merger, American Economic Review Papers and Proceedings, Vol. 40 (2), 23-34.

Vasconcelos, H., 2004, Entry Effects on Cartel Stability and the Joint Executive Committee, Review of Industrial Organization, Vol. 24, 219-241.

Vonortas, N.S., 1997, Research Joint Ventures in the U.S., Research Policy Vol. 26, 577595. 
Table 1. Description of the Variables Used in the Regressions

\begin{tabular}{|c|c|c|c|c|c|c|c|c|}
\hline Variable & & \multicolumn{7}{|c|}{ Description } \\
\hline STABLE & \multicolumn{8}{|c|}{$\begin{array}{l}\text { Dummy equal to one if the RJV did not experience the entry or exit of any firm in any } \\
\text { formation }\end{array}$} \\
\hline SIZE & \multicolumn{8}{|c|}{ Number of for profit participants in the RJV in its formation year. } \\
\hline NON_PROFIT & \multicolumn{8}{|c|}{ Number of non-profit participants in the RJV in its formation year. } \\
\hline HHI & \multicolumn{8}{|c|}{ Herfindahl index in a SIC2 industry based on sales, averaged over the RJV lifespan. } \\
\hline FIRM_SIZE & \multirow{2}{*}{\multicolumn{8}{|c|}{$\begin{array}{l}\text { Median of employees at the SIC2 industry level (in thousand), averaged over the RJV lifesp } \\
\text { Standard deviation of employees at the SIC2 industry level (in thousand), averaged ov } \\
\text { lifespan. }\end{array}$}} \\
\hline FIRM_SIZE_sd & & & & & & & & \\
\hline R\&D INTENSITY & \multirow{2}{*}{\multicolumn{8}{|c|}{$\begin{array}{l}\text { Median R\&D intensity (R\&D expenditures/sales), averaged over the RJV lifespan. } \\
\text { Dummy=1 if the industry is high-tech manufacturing industry according to the AeA }{ }^{7} \text { ( } \\
\text { 3572, 3577, 3651, 3663, 3669, 3671, 3672, 3678, 3679, 3821, 3823, 3825, 3826, 3829, } \\
\text { 3812, 3844, 3845) }\end{array}$}} \\
\hline HightechM & & & & & & & & \\
\hline HightechC & \multicolumn{8}{|c|}{$\begin{array}{l}\text { Dummy }=1 \text { if the industry was hig } \\
\text { 4812, 4813, 4822, 4841, 4899) }\end{array}$} \\
\hline HightechS & \multicolumn{8}{|c|}{$\begin{array}{l}\text { Dummy }=1 \text { if the industry was high-tech software industry according to the AeA (SIC4 } \\
7372,7373,7375,7376,7379 \text { ) }\end{array}$} \\
\hline \multirow[t]{4}{*}{ LINKS } & \multicolumn{8}{|c|}{$\begin{array}{l}\text { Number of links (i.e. average number of other RJVs where insiders in RJV i are preser } \\
\text { averaged over the RJV lifespan. }\end{array}$} \\
\hline & \multicolumn{8}{|c|}{ Table 2. Preliminary Statistics - Variables used in the Regressions } \\
\hline & \multicolumn{4}{|c|}{ Stable } & \multicolumn{4}{|c|}{ Unstable } \\
\hline & Mean & St.Dev. & Min & Max & Mean & St.Dev. & Min & Max \\
\hline SIZE & 6.42 & 13.37 & 1 & 159 & 16.4 & 23.75 & 1 & 180 \\
\hline NON_PROFIT & 0.33 & 1.47 & 0 & 18 & 0.75 & 4.51 & 0 & 52 \\
\hline LINKS & 27.21 & 25.28 & 1 & 123 & 30.30 & 29.53 & 1 & 122 \\
\hline HHI & 0.07 & 0.06 & 0.01 & 0.79 & 0.08 & 0.07 & 0.01 & 0.72 \\
\hline FIRM_SIZE & 0.83 & 0.82 & 0.01 & 5.93 & 0.96 & 1.15 & 0.02 & 5.35 \\
\hline FIRM_SIZE_sd & 2.80 & 0.89 & 0.46 & 4.54 & 2.52 & 0.97 & -1.67 & 4.50 \\
\hline R\&D intensity & 0.07 & 0.07 & 0 & 0.31 & 0.07 & 0.08 & 0 & 0.31 \\
\hline hightechM & 0.16 & 0.37 & 0 & 1 & 0.07 & 0.25 & 0 & 1 \\
\hline hightechC & 0.17 & 0.37 & 0 & 1 & 0.07 & 0.26 & 0 & 1 \\
\hline hightechS & 0.05 & 0.22 & 0 & 1 & 0.14 & 0.35 & 0 & 1 \\
\hline Obs & \multicolumn{4}{|c|}{548} & \multicolumn{4}{|c|}{237} \\
\hline
\end{tabular}

\footnotetext{
${ }^{7}$ The high-tech industries have been identified according to the American Electronics Association (AeA) classification (http://www.aeanet.org/Publications/IDMK_definition.asp).
} 
Table 3. RJVs' Size Distribution and Stability

\begin{tabular}{|c|c|c|c|}
\hline $\begin{array}{l}\text { Number of initial for- } \\
\text { profit insiders (SIZE) }\end{array}$ & Stable & Unstable & Size Classes \\
\hline \multirow[b]{2}{*}{1} & 24 & 1 & \multirow{6}{*}{$\begin{array}{l}\text { Small RJVs } \\
\quad(342)\end{array}$} \\
\hline & $96.00 \%$ & $4.00 \%$ & \\
\hline \multirow[b]{2}{*}{2} & 207 & 6 & \\
\hline & $97.18 \%$ & $2.82 \%$ & \\
\hline \multirow[b]{2}{*}{3} & 89 & 15 & \\
\hline & $85.58 \%$ & $14.42 \%$ & \\
\hline \multirow[b]{2}{*}{4} & 46 & 24 & \multirow{12}{*}{$\begin{array}{l}\text { Medium RJVs } \\
\quad \text { (282) }\end{array}$} \\
\hline & $65.71 \%$ & $34.29 \%$ & \\
\hline \multirow{3}{*}{5} & 35 & 42 & \\
\hline & $45.45 \%$ & $54.55 \%$ & \\
\hline & 33 & 13 & \\
\hline \multirow[t]{2}{*}{6} & $71.74 \%$ & $28.26 \%$ & \\
\hline & 14 & 17 & \\
\hline 7 & $45.16 \%$ & $54.84 \%$ & \\
\hline \multirow{2}{*}{8} & 20 & 14 & \\
\hline & $58.82 \%$ & $41.18 \%$ & \\
\hline \multirow[b]{2}{*}{9} & 13 & 11 & \\
\hline & $54.17 \%$ & $45.83 \%$ & \\
\hline \multirow[b]{2}{*}{10 or more } & 67 & 94 & \multirow{2}{*}{$\begin{array}{l}\text { Large RJVS } \\
\text { (161) }\end{array}$} \\
\hline & $41.61 \%$ & $58.39 \%$ & \\
\hline \multirow[b]{2}{*}{ Total } & 548 & 237 & \multirow{2}{*}{785} \\
\hline & $69.81 \%$ & $30.19 \%$ & \\
\hline
\end{tabular}


Table 4. Probit Regression: The probability of Stability

\begin{tabular}{|c|c|c|c|c|}
\hline & Coefficient & Marginal Effect & Std.Error & \\
\hline SIZE MEDIUM & -1.479 & -0.477 & 0.282 & $* * *$ \\
\hline SIZE LARGE & -2.545 & -0.790 & 0.341 & $* * *$ \\
\hline HHI * SMALL & -1.685 & -0.482 & 1.866 & \\
\hline HHI * MEDIUM & 2.463 & 0.704 & 1.892 & \\
\hline HHI * LARGE & 9.611 & 2.749 & 3.499 & $* * *$ \\
\hline NON_PROFIT*SMALL & 0.050 & 0.014 & 0.300 & \\
\hline NON_PROFIT*MEDIUM & -0.011 & -0.003 & 0.216 & \\
\hline NON_PROFIT *LARGE & -0.296 & -0.085 & 0.153 & $*$ \\
\hline ENTRY_SIC2 & 4.168 & 1.192 & 4.399 & \\
\hline EXIT_SIC2 & -19.789 & -5.660 & 13.188 & \\
\hline FIRM_SIZE & -0.215 & -0.061 & 0.266 & \\
\hline FIRM_SIZE_sd & 0.472 & 0.135 & 0.240 & $* *$ \\
\hline R\&D-INTENSITY & -0.212 & -0.061 & 3.483 & \\
\hline hightechM & -0.115 & -0.034 & 0.249 & \\
\hline hightechC & 0.024 & 0.007 & 0.356 & \\
\hline hightechS & -1.699 & -0.602 & 0.521 & $* * *$ \\
\hline LINKS & -0.030 & -0.009 & 0.061 & \\
\hline \# Obs & & 783 & & \\
\hline Wald-Chi2 & & 336.45 & & \\
\hline Prob & & 0.0000 & & \\
\hline pseudo-loglikelihood & & -269.20 & & \\
\hline pseudo-R2 & & 0.44 & & \\
\hline Sensitivity & & $90.68 \%$ & & \\
\hline Specificity & & $66.95 \%$ & & \\
\hline Correctly classified & & $83.52 \%$ & & \\
\hline
\end{tabular}

All size variables are transformed into logs. We control for industry dummies and for the RJV's year of formation. The reported standard errors are computed using the robust/sandwich estimator. Significance at the $1 \%, 5 \%, 10 \%$ is represented by ***, **, and * respectively 
Bücher des Schwerpunkts Märkte und Politik

Books of the Research Area Markets and Politics

Mark Gradstein, Kai A. Konrad (Eds.)

Institutions and Norms in Economic Development 2007, MIT Press

Johannes Münster

Mobbers, Robbers, and Warriors

2007, Shaker Verlag

Kai A. Konrad, Beate Jochimsen (Eds.)

Der Föderalstaat nach dem Berlin-Urteil

2007, Peter Lang Verlag

Kai A. Konrad, Beate Jochimsen (Eds.)

Finanzkrise im Bundesstaat

2006, Peter Lang Verlag

Robert Nuscheler

On Competition and Regulation in Health Care

Systems

2005, Peter Lang Verlag

Pablo Beramendi

Decentralization and Income Inequality

2003, Madrid: Juan March Institute

Thomas R. Cusack

A National Challenge at the Local Level: Citizens, Elites and Institutions in Reunified Germany

2003, Ashgate

Sebastian Kessing

Essays on Employment Protection

2003, Freie Universität Berlin

http://www.diss.fu-berlin.de/2003/202

Daniel Krähmer

On Learning and Information in Markets and

Organizations

2003, Shaker Verlag

Tomaso Duso

The Political Economy of the Regulatory Process:

An Empirical Approach

Humboldt-University Dissertation, 2002, Berlin,

http://edoc.hu-berlin.de/dissertationen/duso-tomaso-

2002-07-17/PDF/Duso.pdf

Bob Hancké

Large Firms and Institutional Change. Industrial Renewal and Economic Restructuring in France 2002, Oxford University Press

Andreas Stephan

Essays on the Contribution of Public Infrastructure to Private: Production and its Political

Economy

2002, dissertation.de

Peter A. Hall, David Soskice (Eds.)

Varieties of Capitalism

2001, Oxford University Press

Hans Mewis

Essays on Herd Behavior and Strategic Delegation

2001, Shaker Verlag
Andreas Moerke

Organisationslernen über Netzwerke - Die personellen Verflechtungen von Führungsgremien japanischer Aktiengesellschaften

2001, Deutscher Universitäts-Verlag

Silke Neubauer

Multimarket Contact and Organizational Design

2001, Deutscher Universitäts-Verlag

Lars-Hendrik Röller, Christian Wey (Eds.)

Die Soziale Marktwirtschaft in der neuen

Weltwirtschaft, WZB Jahrbuch 2001

2001, edition sigma

Michael Tröge

Competition in Credit Markets: A Theoretic

Analysis

2001, Deutscher Universitäts-Verlag

Torben Iversen, Jonas Pontusson, David Soskice

(Eds.)

Unions, Employers, and Central Banks

2000, Cambridge University Press

Tobias Miarka

Financial Intermediation and Deregulation:

A Critical Analysis of Japanese Bank-Firm-

Relationships

2000, Physica-Verlag

Rita Zobel

Beschäftigungsveränderungen und organisationales Lernen in japanischen

Industriengesellschaften

2000, Humboldt-Universität zu Berlin

http://dochost.rz.hu-berlin.de/dissertationen/zobel-rita2000-06-19

Jos Jansen

Essays on Incentives in Regulation and Innovation 2000, Tilburg University

Ralph Siebert

Innovation, Research Joint Ventures, and

Multiproduct Competition

2000, Humboldt-Universität zu Berlin

http://dochost.rz.hu-berlin.de/dissertationen/siebert-

ralph-2000-03-23/

Damien J. Neven, Lars-Hendrik Röller (Eds.)

The Political Economy of Industrial Policy in

Europe and the Member States

2000, edition sigma

Jianping Yang

Bankbeziehungen deutscher Unternehmen:

Investitionsverhalten und Risikoanalyse

2000, Deutscher Universitäts-Verlag 
Kai A. Konrad

Jo Seldeslachts Joseph A. Clougherty

Pedro Pita Barros

Stijn Goeminne Benny Geys

Carine Smolders

Hilde Coffé Benny Geys

Lutz Engelhardt

Beate Jochimsen Robert Nuscheler

Thomas R. Cusack Torben Iversen David Soskice

Lutz Engelhardt

Benny Geys Jan Vermeir

Kristien Werck Bruno Heyndels

Benny Geys

Benny Geys

Tomaso Duso Enrico Pennings Jo Seldeslachts
Strategy in Contests - an Introduction

Remedy for Now but Prohibit for Tomorrow:

The Deterrence Effects of Merger Policy Tools

Political Fragmentation and Projected Tax

Revenues: Evidence from Flemish Municipalities

Measuring the Bridging Nature of Voluntary

Organizations: A Note on the Importance of

Association Size

Der Entry Standard der Frankfurter Wertpapierbörse als Nachfolger des Neuen Marktes: Zwei

Versuche institutioneller Innovation in Deutschland

The Political Economy of the German Länder Deficits

Economic Interests and the Origins of Electoral Systems

Arbeits- und Kapitalmarktstruktur als Determinanten von Frühphasen-Wagniskapitalinvestitionen

Taxation and Presidential Approval:

Separate Effects from Tax Burden and Tax

Structure Turbulence?

The Impact of 'Central Places' on Spatial Spending

Patterns: Evidence from Flemish Local

Government Cultural Expenditures

How to Make Head or Tail of 'Bridging' and 'Bonding'?: Addressing the Methodological Ambiguity

The Dynamics of Research Joint Ventures: A Panel Data Analysis
SP || $2007-01$

SP || $2007-02$

SP || $2007-03$

SP || $2007-04$

SP II $2007-05$

SP II $2007-06$

SP || $2007-07$

SP || $2007-08$

SP || 2007- 09

SP || $2007-10$

SP || $2007-11$

SP || $2007-12$ 
Dan Kovenock

Brian Roberson

Dan Kovenock

Brian Roberson

Vito Tanzi

Kai A. Konrad Kjell Erik Lommerud

Benny Geys Jan Vermeir

Benny Geys Jan Vermeir

Kai A. Konrad Dan Kovenock

Johannes Münster

Kai A. Konrad

Dan Kovenock

Kai A. Konrad

Florian Morath

Joseph Clougherty Anming Zhang

Jonathan Beck

Susanne Prantl

Jo Seldeslachts

Tomaso Duso

Enrico Pennings
Inefficient Redistribution and Inefficient

Redistributive Politics

Coalitional Colonel Blotto Games with Application to the Economics of Alliances

The Future of Fiscal Federalism

Love and Taxes - and Matching Institutions

Party Cues and Yardstick Voting

The Political Cost of Taxation:

New Evidence from German Popularity Ratings

The Alliance Formation Puzzle and Capacity Constraints

Repeated Contests with Asymmetric Information

Competition for FDI with Vintage Investment and Agglomeration Advantages

Non-binding Minimum Taxes May Foster Tax Competition

Strategic Information Acquisition and the Mitigation of Global Warming

Domestic Rivalry and Export Performance: Theory and Evidence from International Airline Markets

\section{Diderot's Rule}

The Role of Policies Supporting New Firms: An Evaluation for Germany after Reunification

On the Stability of Research Joint Ventures: Implications for Collusion
SP || $2008-05$

SP II $2008-01$

SP II $2008-02$

SP || $2008-03$

SP || $2008-06$

SP II $2008-07$

SP || $2008-08$

SP || $2008-09$

SP || $2008-10$

SP || $2008-11$

SP || $2008-12$

SP || $2008-13$

SP || $2008-14$

SP || $2008-15$
SP || 2008-04 
Bei Ihren Bestellungen von WZB-Papers schicken

Sie bitte unbedingt einen an Sie adressierten Auf-

kleber mit sowie je paper eine Briefmarke im Wert

von 0,51 Euro oder einen "Coupon Reponse Inter-

national " (für Besteller aus dem Ausland)
Please send a self addressed label and postage stamps in the amount of 0.51 Euro or a "CouponReponse International" (if you are ordering from outside Germany) for each WZB-paper requested

Absender I Return Address:

Wissenschaftszentrum Berlin

für Sozialforschung

Presse- und Informationsreferat

Reichpietschufer 50

D-10785 Berlin-Tiergarten

Hiermit bestelle ich folgende(s) Discussion paper(s):

Please send me the following Discussion paper(s):

Bestell-Nr. I Order no.

Autor/in, Kurztitel /Author(s) / Title(s) in brief 